\title{
THE GOLD COAST WHEN EDWARD IV. WAS KING
}

THERE was a period in remote times when the enterprising merchants of Europe were attracted by the wealth of the Gold Coast more than they were to any other part of the Western Coast of Africa bordering the Gulf of Guinea. Portuguese and Dutch, French and English, with an occasional Dane and Swede all traded here, and built factories, called forts, some of which remain to this day.

The Gold Coast is now a British possession, but it is not generally known that as far back as 1482, when Edward IV. was King of England, some enterprising Englishmen did a very profitable trade to their entire satisfaction, not only at Cape Tres Punctos, that is, Cape Three Points, but also at Mowure At Cape Tres Punctos, called by the inhabitants Atinkin, is now a fine lighthouse, which one passes on his way eastward to Sekondi port, where the traveller of to-day goes to Kumasi through the Tarkwa Gold Fields. Mowure is still a large flourishing town of the Asaibu district, but situate about three miles on the east of Cape Coast Castle. Fort Nassau, built here by the Dutch in 1637 , is now in ruins. The inhabitants of this ancient town are mainly engaged in fishing. By popular tradition it was near this populous town that the founder or first ruler of Asaibu, Amamfi by name, a giant, landed with his sister, and Kwagya, another giant, and their large retinue from the sea. On reaching the hill Abiriwanfu (meaning " too steep for old women to climb"), the bands of these two leaders separated. Amamfi's band travelled by Akotekiwa to Asaibu, where they dwelt; and the wonderful deeds and exploits of Asaibu Amamfi are still rehearsed to children at nights in many a village in Fantiland. Kwagya, with his followers, going west, settled at Mowure. 
Bosman, Barbot, and others who have written on the Gold Coast, do not seem to have been aware of this English expedition in 1482. If my recollection is correct, Bosman took the credit of being the first writer to give an account of the Gold Coast ; it is, however, probable, there exists an earlier work by a Portuguese or French traveller. In the History of the Gold Coast and Asante, by the Rev. Carl Christian Reindorf (a native of Accra, Gold Coast) there appears a brief historical account of several European voyages to the Gold Coast. Dates are given, but the able and well-informed author does not give the sources of his information. A reference, however, to Barbot's work gives one the impression that this was his authority. According to Barbot, the first Englishman who traded on the Coast of Guinea was one Thomas Windham, who made two voyages in 1551 and 1552 to Zaphin or Saphia and Santa Cruz. In 1553 he made a third voyage. Sailing from Portsmouth to Guinea for gold, he proceeded as far as Benin and returned to Plymouth with little wealth. In I554 one John Lock undertook a voyage to Guinea with three ships, and, trading along the coast, brought away a considerable quantity of gold and ivory. There exists an interesting account of this third voyage of Thomas Windham, wherein mention is made of some of the aboriginal customs and institutions. The Fanti, and his brother the Ashanti, can take pleasure in the thought that their common language is not of recent growth, and the word Dask, meaning a present, used by every Englishman travelling in West Africa, is, after all, a Fanti word, originally written Dache, just as Kwesi became Quashie. For services rendered to the early voyagers the inhabitants expected something by way of thanks, and said Dasi (give thanks), for the African way to give thanks is to offer a present to one's benefactor. In these far-off times our ancestors had their weights and measures; benda, that is, two ounces of gold, was the highest weight. The customary law of succession was the same as now, and, like us, they called and prayed to God as Yankupon.

The investigation of West African customary laws and institutions is no doubt interesting and instructive, but it seems to me, the study of the history of European intercourse with West Africa is a fascinating one. The early Portuguese traders 
first called this part of the world Costa d'Oro, and by the English was known as the Golden Coast of Guinney. So when the "Company of Royal Adventurers of England trading to Africa" was formed in the days of Charles II., English enterprise was further stimulated by several writers who pretended to point out the way how to be rich there in four years. For the Golden Coast, as one quaintly wrote, was a region "where a man may gain an estate by a handful of beads, and his pocket full of gold for an old hat; where a cat is a tenement, and a few fox-tails a manor ; where gold is sold for iron, and silver given for brass and pewter."

To show that these early adventurers did things in a very business-like way, at one of their meetings sixteen resolutions were passed, including a call of $£ 29$ 6s. for every $£ 100$ value share, and this, "That you deal honestly and courteously with the Ethnicks, ${ }^{1}$ so as to procure their friendship and good liking. Especially you must take care of your word and promise," which is evidently one of the general instructions to their agents and servants.

And now to the interesting original relation concerning Sir John Tintam and Sir Pierce Fabian in the year $148 \mathrm{r}$ in the days of Edward IV.: "Sir John Tintam, and Sir William Fabian, the great Mathematicians and Geographers of those times, having spirits above the model of their age, and the narrowness of their fortunes; and hearing of the Portugals rich discovery upon the Coast of Guinney and Terra Nigritarixm (as Keckerman confesseth, that we are the best adventurers in the world) joined heads and purses to set out some English vessels with Hanse towns mariners, for the trade of Guinney. While they were setting out, John the Second, King of Portugal, upon the Frenchmen's suggestion (with whom we had great sea fights at that time, and by fighting with whom we grew expert at sea) sent Ruy de Sousa, with Dr. de Elvas, and Ferdinando de Pina, to confirm the ancient league with England, and desire the King to dissolve the aforesaid fleet, which the King did. But the Duke of Medina Sidonia encouraged the aforesaid gentlemen, insomuch that they appeared at Cape Verde, the 5th of March 1482, and making no stay there, crept along the

\footnotetext{
1 Probably a misprint for " Ethiopica" - Editor.
} 
coast to Rio de Festos the 8th of April, whence all the French on the coast fled upon the first sight of them. They trafficking securely and understanding of the Negroes the state of the country, who directed them to Rio de Pontes and to the river St. Andras, where a great ship and carvel of the King of Portugal shot at them. But they getting to the foremost of them slipped between them and the Castle De Tres Punctos, where the English beat them, to the no small joy of the Negroes, as well as the security of themselves, whom the inhabitants invited to Mowre, some three leagues behind, where they saw was the best place to trade with them, considering the strength of the Portuguese. Whither they brought more gold than they knew what to do with. Here they had a hundred pounds worth of pewter, sixty-five of . . . brass; an hundred twenty-four pound, thirteen shillings sixpence of iron. For which they carried away two hundred sixty-seven elephants teeth, weighing two thousand seven hundred fifty-eight pound; and grains sixty-five butts full, all along the coast of Rio de Festos and Rio de Barbos, which at last they improved to a million, half whereof they paid the Duke their Patron, and half they divided among themselves, who were within three years able to buy their traffic with Portugal, and their peace with England, putting up an hundred thousand pounds apiece in their purses: for Sir P. Fabian, nephew to Sir William, died the richest subject in Medina." 